\title{
Study of Energy Saving for Fish Preservation by Refrigeration SystemBased on Ozone Technology
}

\author{
Muhammad Nur $^{\# 1}$, K. Sofjan Firdausi ${ }^{\# 2}$, Ade Ika Susan ${ }^{\# 3}$, Andi Wibowo Kinandana ${ }^{\# 4}$, Fajar Arianto ${ }^{\# 5}$, \\ SaifurRijal $^{\# 6}$,Eva Sasmita ${ }^{* 7}$, MelizaPuspita ${ }^{+8}$, Yuliani ${ }^{+9}$, IntanZahar ${ }^{\# 10}$, EkoYulianto ${ }^{\# 11}$, and Azwar \\ Usman $^{\& 12}$ \\ \#Department of Physics, Faculty of Science and Mathematics, Diponegoro University, Semarang, Indonesia \\ * Department of Biology, Faculty of Science and Mathematics, Diponegoro University, Semarang, Indonesia \\ ${ }^{+}$Faculty of Fishery and Marine Science, Diponegoro University, Semarang, Indonesia \\ ${ }^{\&}$ PT. Dipo Technology, Plasma Technology Company, Semarang, Indonesia \\ ${ }^{1}$ m.nur@undip.ac.id, ${ }^{2}$ firdausi@fisika.undip.ac.id, ${ }^{3}$ adeika.susan@st.fisika.undip.ac.id \\ ${ }^{4}$ andikinandana@st.fisika.undip.ac.id, ${ }^{5}$ ariantofajar@gmail.com, ${ }^{6}$ saifur.rijal@st.fisika.undip.ac.id \\ ${ }^{7}$ sasmitaeva@gmail.com, ${ }^{8}$ melizapuspita@gmail.com, ${ }^{9}$ yuliani234@gmail.com \\ ${ }^{10}$ intanzahar@st.fisika.undip.ac.id, ${ }^{11}$ ekoyuli@st.fisika.undip.ac.id, ${ }^{12}$ azwar4213@gmail.com
}

\begin{abstract}
Research on ozone application to extend the shelf life of fresh fish in the refrigerator has been done. Refrigerators where fresh fish deposits are ozone fed through piping systems. Ozone is produced by using Dielectric Barrier Discharge Plasma (DBDP) reactor. The refrigerator has 3 compartments and 1 freezer that has a total volume of $400 \mathrm{~L}$. Ozone loading was done 2 times a day. Ozone can be evenly distributed at $6 \mathrm{mg} / \mathrm{L}$ at each compartemnts and freezer. Ozone will last for 60 minutes in the refrigerator. A refrigerator of the same type (but not ozonezed) is provided to place the fish as a control. The fish used in both refrigerators was mackerel fish. The quality of fish were controled by Total Volatile Base Nitrogen (TVBN) and Trimethyl Amin nitrogen (TMA-N) using INS 2354.8: 2009 standard. The freshness of fish was determined through organaleptic number by using INS 01-2729.12006 standard. The results of this study reported that the ozonized refrigerator can maintain the quality of fish in a longer timeframe.The results showed that the value of the fish in the refrigerator TVBN powered ozone standards are still maintained in the range of fresh fish in accordance with INS, which is below the value of 30 . While the value TVBN in fish stored in a refrigerator is not energized ozone tends to be higher than those fed ozone, TVBN value in fish stored in the refrigerator without ozone wasperishable on the 12th day of each compartment, reaching 30, except in the freezer compartment. On the 16th day, through comparasion of fish freshness (TVBN value), refrigerator not powered by ozone can only be represented by fish stored in the freezer at tempertaure of $-9.28^{0} \mathrm{C}$. On the 16 th day, energy consumed by refrigerator not powered by ozonewas $34.26 \mathrm{kWh}$ (or 2.66 US \$) compared to $9.23 \mathrm{kWh}$ (or 0.72 US \$) for refrigerator powered by ozone. These results indicate a huge energy savings by utilizing ozone in the refrigerator. The savings was up to $73 \%$.
\end{abstract}

\section{INTRODUCTION}

Approximately 7.9 millions ton diesel oils was consumed by about 1,06 million fishing vessel in China per year[1]. It should be noted that more than $50 \%$ energy was also used to drive cooling system for ice making and air conditioning considering that about 1 ton of fish requires 1.5-2.0 ton ice. Prevention of bacterial growth and freshness damage of fishery harvested due to extra-cold temperature usually conducted at the range room temperature between $-1{ }^{\circ} \mathrm{C}$ to $0{ }^{\circ} \mathrm{C}[2]$.

Storage of fish in cold storage is generally carried out at negative temperatures well below water freezing temperature. Storage at this temperature consumes a lot of electrical energy. Therefore, a breakthrough for operating cold storage at temperatures above zero is urgently needed. Several attempts have been made by researchers to meet those needs. A number of engineering technology has been developed to minimize the use of fuel and reduce operating costs for the fishermen. Hoang et al have used superchilling technology to raise the shelf temperature for salmon in the refrigerator [3]. The combination of ozone and slurry ice has been used by Nur et al, ozone that was delivered periodically into cold storage can save red tilapia for 16 days [4].

Research of energy saving on the use of refrigerators in fishing vessels was done by Zisheng and Ruzhu. They used the method of pressure-heat recovery and multi-step heat recovery processes [5]. This technique may reduce energy for cooling by $18 \%[5,6]$. 
Many studies have been conducted related to fishery harvestedhandling at low temperatures such as freezing [7], using ice [8], chilling [9] and using slurry ice [10,11]. Moreover, the use of chemical preservatives such as chlorotetracycline, sodium chloride,ellagic acid, L-ascorbic acids, and chlorine dioxyde $\left(\mathrm{ClO}_{2}\right)$ to extend the shelf-life of fish at low temperature have been used $[12,13]$.

Sterile and ozonized water has been used to wash fish and to manufacture ice in flakes (Petfrost system). The fish stored wasrefrigerated in the holds of boats for a period of up to 18 days. Later, once on shore, they were further kept and refrigerated up to 12 days at $2{ }^{\circ} \mathrm{C}$. This method has been used to study the effectiveness of sterile and ozonized water in the conservation of fresh fish [13].

This study assesed the potential of energy saving in fish storage systems with applying ozone-tech for refrigerator. In the future, this technology is expected to be able to applied in fish storage systems on fishing vessels.In addition to maintain the quality of fish better and longer, the application of ozone technology is expected to suppress the use of fossil fuels which leads the operational costs suppression for the fishermen. Based on a research, ozone technology can be applied for fish storage in the whole journey from harvested to it's distribution to the consumers. Previous research has been done on the red tilapia, which represents white-fleshed fish, in the refrigerator where ozone was delivered with a concentration of 0.5-45 ppm. The TVBN test results showed that fish on each shelf in the refrigerator with ozone treatment still meet Indonesian NationalStandard (INS)[14,15], until the 16th day. In contrast, fish placed on refrigerators with no ozone treatment have an untoleratedtvbn value on the 8th day.

This paper reports the results obtained from research on the development of ozone-tech fish storage system which was implemented in a refrigerator. Calculation of energy consumption in the refrigerator take into account the energy required to release the heat on the fish $(\mathrm{Q})$ to achieve a certain temperature which is able to maintain the quality of the fish.In addition, ozone was reported be able to maintain fish quality in a longer range than the storage system without ozone. Moreover, the ozone treatment may maintain the freshness of fish (TVBN) within the range of Indonesian National Standard (INS) though the temperature of refrigerator is relatively higher than the freezing temperature. By setting the refrigerator temperature at the medium scale, the energy saving in electricity power consumption for the cooling system can be achieved.The energy consumption profit can be converted into electricity tariff per $\mathrm{kWh}$, so that some dollars can be saved.

\section{METHOD}

\subsection{Ozone generation with DBD Plasma System}

Ozone utilized to treat fish in this research was produced from an ozone generator consists of DBD plasma reactor and an high voltage power supply. Figure1 shows a series of storage systems for fish using ozone technology in a refrigerator.DBD plasma reactor hasa spiral-cylindricalconfiguration which consists of inner and outer electrodes separated by a pyrex tube glass as a dielectric materials. The discharge in the reactor was generated by an AC high voltage, with the specification of $0-25 \mathrm{kV}$ and frequency up to $23 \mathrm{kHz}$. ). The electrical signal was detected with oscilloscope (Oscilloscope GOS-653.50 MHz) connected to a probe as voltage reader expander device (HV Probe max DC Voltage DC 40 kV; 28 kV AC EC code number 1010, En G1010). Beside it, electric current generated in the reactor was measured using a multimeter (SunwaTRXn 360). The gas source for the reactor used in this research is free air from an air pump and flowed to the reactor with flow rate of 10 $\mathrm{L} / \mathrm{min}$. The ozone concentration was measured using an ozone sensor (Quant Ozone "2", made in USA, 0-20 ppm). Ozone generated $(10 \mathrm{mg} / \mathrm{L})$ was delivered into refrigerator(TOSHIBA CR-N189GHI, Volume $400 \mathrm{~L}$ ) through an elastic pipe with 4 branches which placed in 4 shelfs; i.e. shelf 1,2,3, and freezing compartment for 30 minutes every day.Ozone concentration applicatedinside of fish storage system by ozone technology in refrigerator (Fig.1) can be determinated. The concentration of ozone in the refrigerator is the ozone concentration generated by the generator multiplied by the flowrate and divided by the volume of the refrigerator [14]. In this study we used ozone concentraion inside refrigerator was $6 \mathrm{mg} / \mathrm{L}$.

\subsection{Ozone-Treatment for Fish}

Ozone treatment was conducted to obtain the effect of ozone in maintaining fish freshness longer than non-ozone storage. Two refrigerators were used to compare the conditions of fish treated with and without ozone, therefore one refrigerator was degassed with ozone while the other one was not. Amount of $16 \mathrm{~kg}$ of fish divided into eight groups to be placed in 8 shelfsin two refrigerators, each shelf contains about $2 \mathrm{~kg}$ of fish.The temperature control in two refrigerators was set at the medium temperature which resulted in different temperatures in each shelf. Thecondition of different temperature in each shelf occursdue to the cooling processgoes from top to bottom, as the coolant flows enter the refrigerator from the freezer compartment to the shelfslower.In addition, the ozone addition into refrigerator also resulted in higher temperature than that in nonozone refrigerator. The temperature in each shelf can be seen in Table 1. 
The different temperature will resulted in different effect of freshness in fish, therefore the freshness level for fish in each shelf required to be evaluated. The fish freshness has been evaluated through Total Volatile Base Nitrogen (TVBN) test that well known in the field. Determination of fish freshness level tolerated to be consumed from TVBN values were based on ISO 2354.8: 2009 released by the INS $[15,16]$.

Table 1. Temperature in each shelf in two refrigerators

\begin{tabular}{|l|c|c|}
\hline \multirow{2}{*}{ Refrigerator Shelf } & \multicolumn{2}{|c|}{ Temperature ( ${ }^{\mathbf{0}} \mathbf{C}$ ) } \\
\cline { 2 - 3 } & Non-ozone (control) & With ozone (sample) \\
\hline Freezer shelf & -9.28 & -4.91 \\
\hline Shelf 1 & 4.75 & 4.85 \\
\hline Shelf 2 & 5.74 & 6,10 \\
\hline Shelf 3 & 8,54 & 9,27 \\
\hline
\end{tabular}

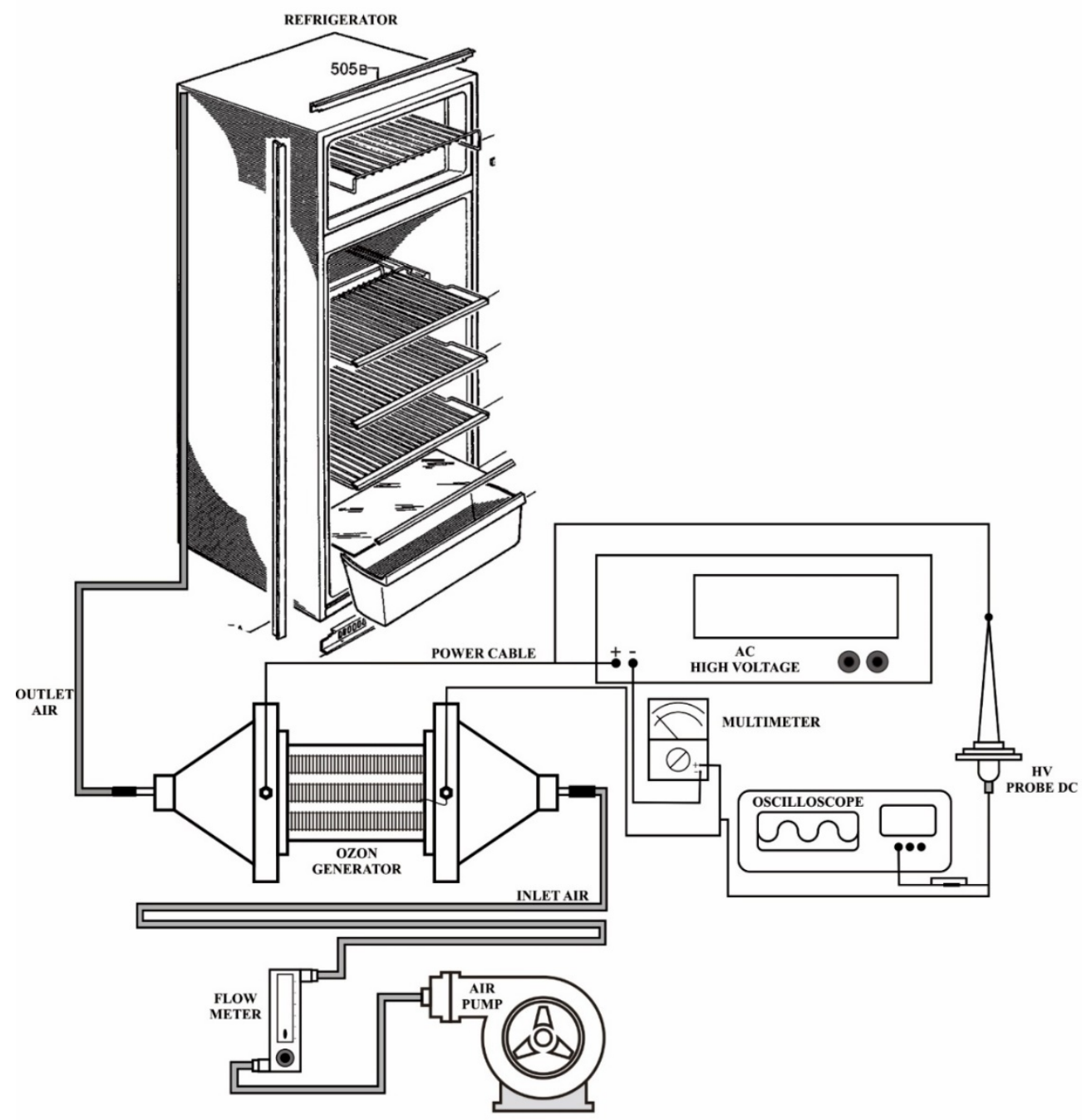

Fig. 1.Experimental set up of fish storage system by ozone technology in refrigerator

\subsection{Energy saving calculation}

Energy savings in the use of refrigerators in various purposes is very important. Many studies about it, among others $[17,18]$. Energy savings calculation was conducted based on the implementation of ozone generate system applied in refrigerator. The comparison of energy consumption was conducted by comparing the energy consumed by 'non ozone freezer shelf' and 'with ozone shelf 1'. Both of shelfs were selected in order to compare the energy required to store fish, in the same mass, between in below freezing temperature without and above freezing temperature with ozone. Energy consumption calculated based on the calculation of heat energy absorbed follows equation 1 , 


$$
Q=m \cdot c \cdot \Delta T,
$$

where $Q$ is the heat energy absorbed (Joule), $m$ is mass of the material or product being stored $(\mathrm{kg}), c$ is specific heat of a matter $\left(\mathrm{J} / \mathrm{kg} .{ }^{\circ} \mathrm{C}\right)$, while $\Delta T$ is the heat difference $\left({ }^{\circ} \mathrm{C}\right)$ between higher temperature $\left(\mathrm{T}_{2}\right)$ and lower temperature $\left(T_{1}\right)$. Meanwhile, the fishused in this research is red tilapia which has a specific heat of $3.6276 \mathrm{KJ} /$ $\mathrm{kg} . \mathrm{K}[19]$.In addition, to calculate the electrical energy consumed also calculated by conversing the heat energy obtained into electrical power (Watt) following equation 2.

$$
E=Q / t
$$

where $E$ is electrical energy (Watt), and tis time to lower the temperature (second). Furthermore, determination of energy consumption can be conducted by converting electrical power into the unit of $\mathrm{kWh}$. The comparison of energy saving further can be performed by using the electricity tariff per kWh.

\section{RESUlTS AND Discussion}

The main objective of this study is to assess the potential energy savings that can be achieved in fish storage systems utilizing ozone technology, and it is environmentally friendly and safe. The outcome of this study are expected to implement ozone technology in storage systems of fish on board fishing vessels, which leads to fuel savings for the cooling system on the hold-hatch fish storage.

\section{A. TVBN Test}

An alternative method for determining the freshness of fish is to measure the total amount of volatile compounds of nitrogen bases (TVBN). TVBN concentration increases with increasing storage time. TVBN content measurement method used to determine the rate of Fish deterioration based on some volatile bases such as trimethyl amine (TMA), dimethyl amine (DMA), TMAO low as bream [8].

TVBN resulted on samples of fish stored in a refrigerator in each compartment are shown in Fig2. the comparison value TVBN shown in the graphs comparison. The results showed that the value of the fish in the refrigerator TVBN powered ozone standards are still maintained in the range of fresh fish in accordance with INS, which is below the value of 30 . While the value TVBN in fish stored in a refrigerator is not energized ozone tends to be higher than those fed ozone, TVBN value in fish stored in the refrigerator without ozone wasperishableon the 12th day of each compartment, reaching 30, except in the freezer compartment. TVBN content of the samples increased and varied on samples. The limit of acceptability for freshness of fish is 30-35 mg N\%. The fish samples without ozone treatment from compartment 1, 2 and3 showed exceed the limit acceptability. Whereas for samples stored in freezer both for ozone and without ozone performed below limit. This evidence showed that low temperature is more effective in retarding the fish deterioration in this case the rate of bacterial activity can be slowed down significantly, so that TVBN content is less in freeze temperature compared to that of low temperatures.

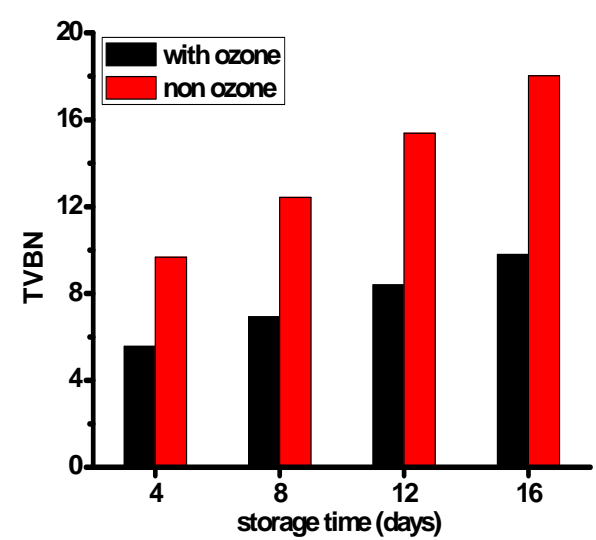

Fig. 2. TVBN changes of fish in with ozone freezer $\left(-4.91{ }^{\circ} \mathrm{C}\right)$ and non-ozone freezer $\left(-9.28^{\circ} \mathrm{C}\right)$ as function of storage time

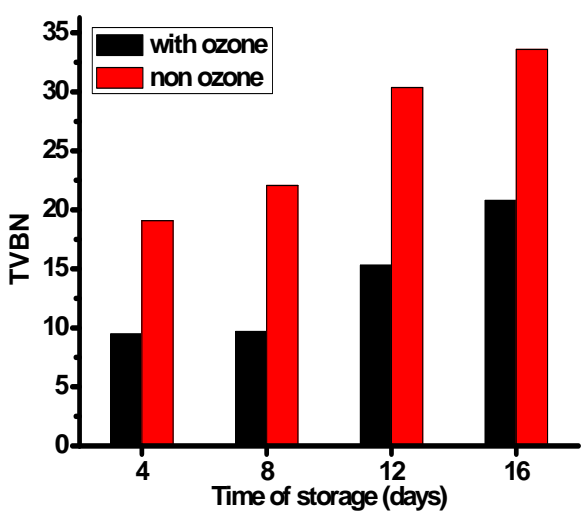

Fig. 3. TVBN changes of fish in with ozone compartment 1 $\left(4.85^{\circ} \mathrm{C}\right)$ and non-ozone compartment $1\left(4.75^{\circ} \mathrm{C}\right)$ as function of storage time 


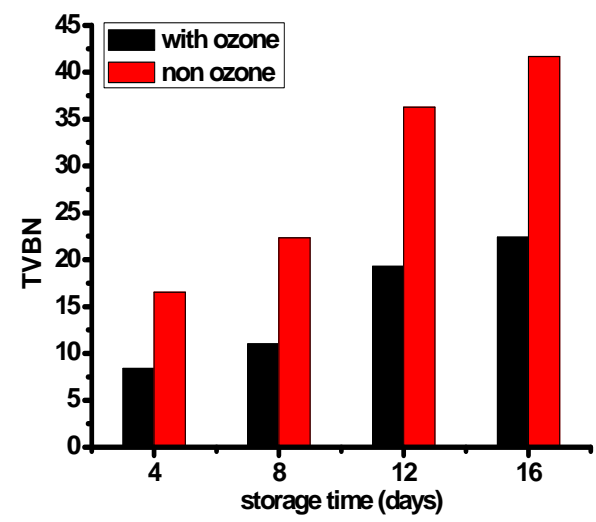

Fig. 4. TVBN changes of fish in with ozone compartment $2(6,10$ ${ }^{\circ} \mathrm{C}$ ) and non-ozone compartment $2\left(5.74{ }^{\circ} \mathrm{C}\right)$ as function of storage time

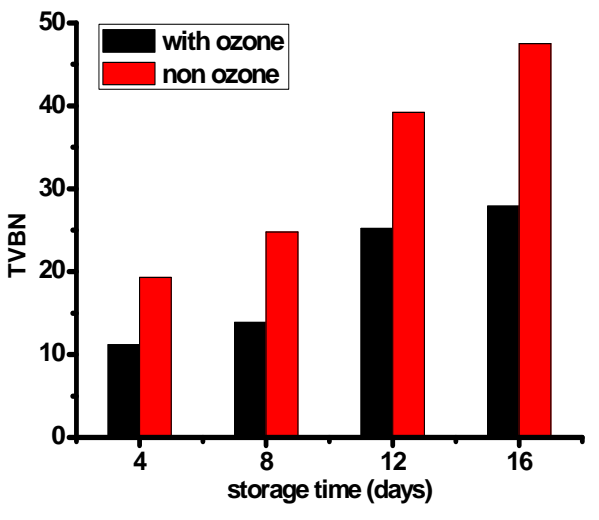

Fig. 5. Comparison of TVBN changes of fish in with ozone compartment $3\left(9,27^{\circ} \mathrm{C}\right)$ and non-ozone compartment $3\left(8,54{ }^{\circ} \mathrm{C}\right)$ as function of storage time

\section{B. TemperatureAnalysis in refrigerator}

The temperature in each compartment was observed for subsequent in the calculation of the energy required to release the heat on the fish (Q) to achieve a certain temperature to maintain the quality of the fish. Table 2, 3 and 4 show temperature data in each compartment in refrigerator, one of the two refrigeratorswas degassed with ozone and the another one wasn't..

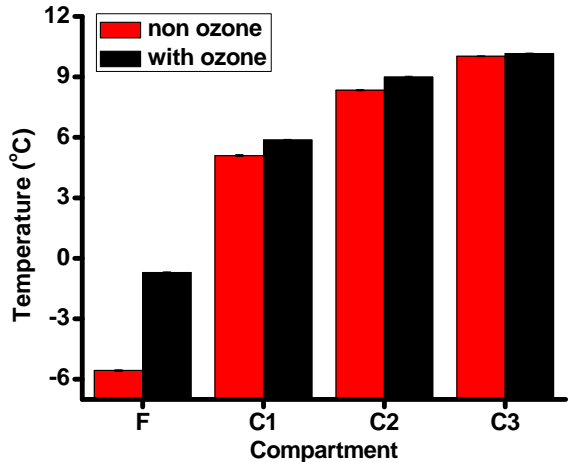

Fig. 6. Comparison of temperatures in each compartment in the refrigerator at the minimum setting

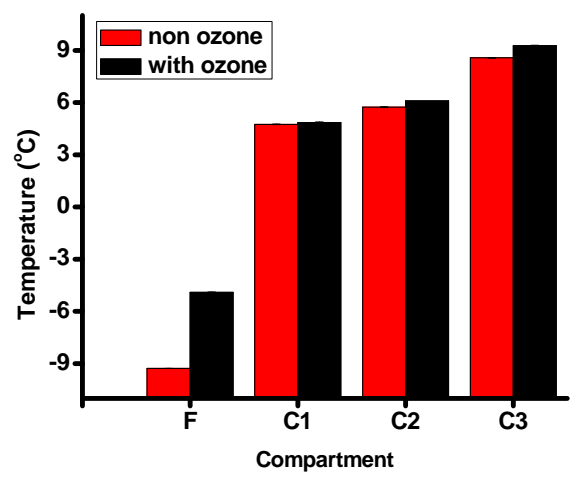

Fig. 7. Comparison of temperatures in each compartment in the refrigerator at the medium setting

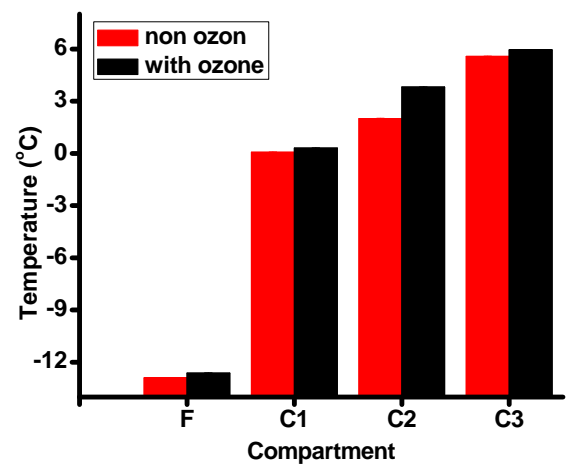

Fig. 8. Comparison of temperatures in each compartment in the refrigerator at the maximum setting

Based on data in Table 2, 3, and 4 can be seen that there is a temperature difference between ozone powered refrigerator with freezer without ozone. The temperature inside the refrigerator that flowed ozone tends to be higher than the refrigerator without ozone. This happens because of the presence of air in the form of ozone that is inserted into the refrigerator, while the use of ozone generated by free air introduced into the reactor ozone by 
high voltage, the input temperature is higher than the temperature in the refrigerator so as to make the temperature in a refrigerator that flowed ozone higher than the refrigerator without ozone.

Although the temperature is higher, the fish were stored in a refrigerator that flowed TVBN ozone is able to maintain its value better than the fish were stored in a refrigerator without ozone.The number of bacteria contained in the fish body has to do with the condition of the waters where the fish live.Bacteria commonly found in fish are: Pseudomonas, Alcaligenes, Micrococcus, Sarcina, Vibrio, Favobacterium, Crynebacterium, Serratia, and Bacillus.In addition to the above mentioned bacteria, for fresh fish there are also bacteria Aeromonas, Lactobacillus, Bevibacterium and Sreptococcus.Bacteria cause more damage, when they are associated with autolysis.In the case of a bacterial phenomenon can be present in large quantities, as a result of previous events. The bacteria are initially followed together with the autolysis, and then walk equally.In our research, the fish were stored in a refrigerator, and the quality of fish can be mentained. This is due to ozone can deactivate microbial properties of bacteria that cause damage to fish $[4,20,21,22]$

\section{Calculation of energy consumption}

Ozonizing process proved able to keep the quality of foodstuffs, so that the material is much more durable when subjected to the storage process. In this study, the fish became the object observed to changes in quality when subjected to the storage process. The variables were observed in this study was the influence of temperature and storage time to change the quality of the fish TVBN experiencing and not experiencing ozonized process. TVBN measurement results can be seen in Figure 2-5.

In principle, in the calculation of engine power on the refrigerator, there are three stages. Initial cooling stage, the temperature change material initially be the same as the temperature of the room refrigerator. At this stage compressor works maximum, so that the material has decreased temperatures up to the specified temperature limit. The second phase, which is the stage where the compressor is turned off. Material temperature will rise, until the predetermined limit. The last stage, which is the stage where the compressor will go back to work. The operation of the compressor resulting in material temperature has decreased to a predetermined limit. The following table power calculation on a working refrigerator in every condition.

In this study used materials, namely mackerel fish. Mackerel has a calorific value of the type $3330 \mathrm{~kg} /$ Joule.K and a mass of $8 \mathrm{~kg}$. So that we can calculate the required power the refrigerator in the preservation process.

TABLE I. Non-ozone Freezer temperature in the refrigerator

\begin{tabular}{|c|c|c|c|c|c|}
\hline \multicolumn{2}{|c|}{ Preliminary condition } & \multicolumn{2}{c|}{ Off Compressor } & \multicolumn{2}{c|}{ On Compressor } \\
\hline Time & Temperature & Time & Temperature & Time & Temperature \\
\hline 0 & 24,7 & 0 & $-15,9$ & 0 & $-5,7$ \\
\hline 240 & $-15,9$ & 20 & $-5,7$ & 10 & $-15,8$ \\
\hline & $\Delta \mathrm{T}: 40,6$ & & $\Delta \mathrm{T}: 10,2$ & & $\Delta \mathrm{T}: 10,1$ \\
\hline
\end{tabular}

TABLE II. With ozone Compartment 1 temperature in refrigerator

\begin{tabular}{|c|c|c|c|c|c|}
\hline \multicolumn{2}{|c|}{ Preliminary condition } & \multicolumn{2}{c|}{ Off Compressor } & \multicolumn{2}{c|}{ On Compressor } \\
\hline Time & Temperature & Time & Temperature & Time & Temperature \\
\hline 0 & 24,5 & 0 & $-2,7$ & 0 & 0 \\
\hline 240 & $-2,7$ & 20 & 0 & 10 & $-2,7$ \\
\hline & $\Delta \mathrm{T}: 27,2$ & & $\Delta \mathrm{T}: 2,7$ & & $\Delta \mathrm{T}: 2,7$ \\
\hline
\end{tabular}

So from the above data can be used to determine the power of each condition, ie, :

\section{1) Preliminary conditions:}

Freezer is used, when first turned on will require more energy to change the initial temperature $\left(24.7^{\circ} \mathrm{C}\right)$ high until the temperature minimum $\left(-15.9^{\circ} \mathrm{C}\right)$. Obviously, the compressor that is used will work longer. On this measure, the old compressor operation in the initial condition is 4 hours.

\section{2) Compressor Off}

This condition is a condition in which the temperature has reached the minimum level. So automatically, the compressor will be off. The minimum temperature is $\left(-15.9^{\circ} \mathrm{C}\right)$. This condition last 20 minutes until the temperature has increased to the limit temperature $\left(-5.7^{\circ} \mathrm{C}\right)$. In this condition, burdened by power supporting components in a refrigerator, such as electronic components, lamps, etc. So, in this case, we can ignore the power load. 
3) Condition compressor on for a second time:

This condition is a condition in which the compressor back on. This condition occurs due to the rise in temperature to a maximum limit value $\left(-5.7^{\circ} \mathrm{C}\right)$. The compressor will continue to start in order to maintain the temperature in the room refrigerator. In this condition, the temperature will decrease to the minimum return temperature $\left(-15.8^{\circ} \mathrm{C}\right)$. This condition occurs for 10 minutes. So that when accumulated, the process for the second time compressor abuse occurred 40 times in one day on the first day. This occurs because, the first day of the initial conditions influenced early livelihood conditions for 4 hours. The next day, this is the case for 48 times a day.

So, the comparison of energy and fee (in US\$) needed in each refrigerator with time variation is:

TABLE III. Comparison of energy, charge and TVBN of fish in the non-ozone freezer and with-ozone compartment 1

\begin{tabular}{|c|c|c|c|c|c|c|}
\hline \multirow{2}{*}{ Days } & \multicolumn{2}{|c|}{ Energy (kWh) } & \multicolumn{2}{c|}{ Charge (in US\$) } & \multicolumn{2}{c|}{ TVBN } \\
\cline { 2 - 7 } & $\begin{array}{c}\text { Non-ozone } \\
\text { Freezer }\end{array}$ & $\begin{array}{c}\text { With ozone } \\
\text { Compartment 1 }\end{array}$ & $\begin{array}{c}\text { Non-ozone } \\
\text { Freezer }\end{array}$ & $\begin{array}{c}\text { With ozone } \\
\text { Compartment 1 }\end{array}$ & $\begin{array}{c}\text { Non-ozone } \\
\text { Freezer }\end{array}$ & $\begin{array}{c}\text { With ozone } \\
\text { Compartment 1 }\end{array}$ \\
\hline 4 & 8.43 & 2.33 & 0.66 & 0.18 & 9,67 & 9,47 \\
\hline 8 & 17.04 & 4.63 & 1.32 & 0.36 & 12,42 & 9,69 \\
\hline 12 & 25.65 & 6.93 & 1.99 & 0.54 & 15,38 & 15,30 \\
\hline 16 & 34.26 & 9.23 & 2.66 & 0.72 & 18,03 & 20,80 \\
\hline
\end{tabular}

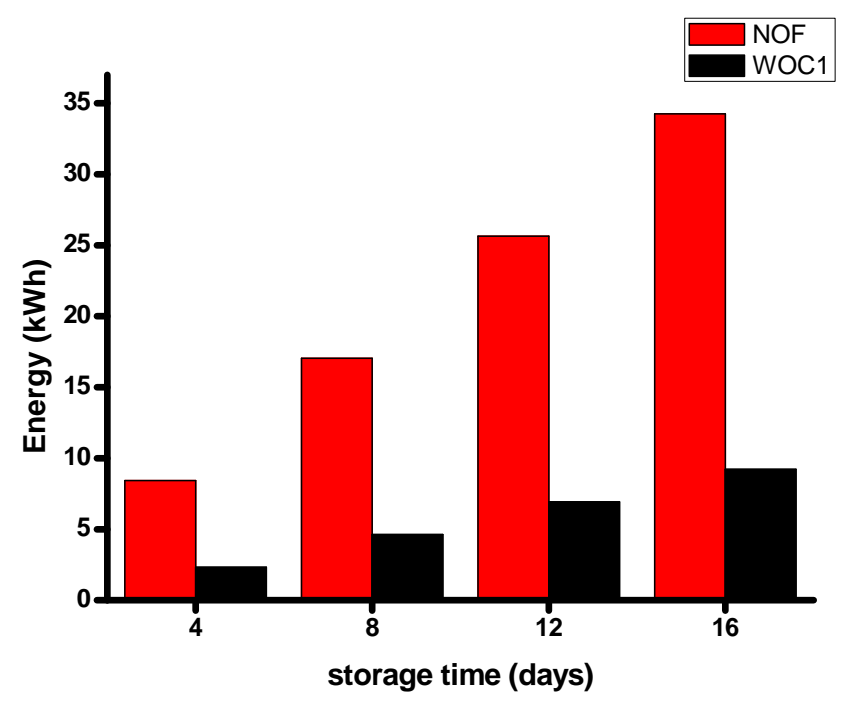

Fig. 9. Comparison of energy consumption in non-ozone freezer and with ozone compartment 1 as function of storage time

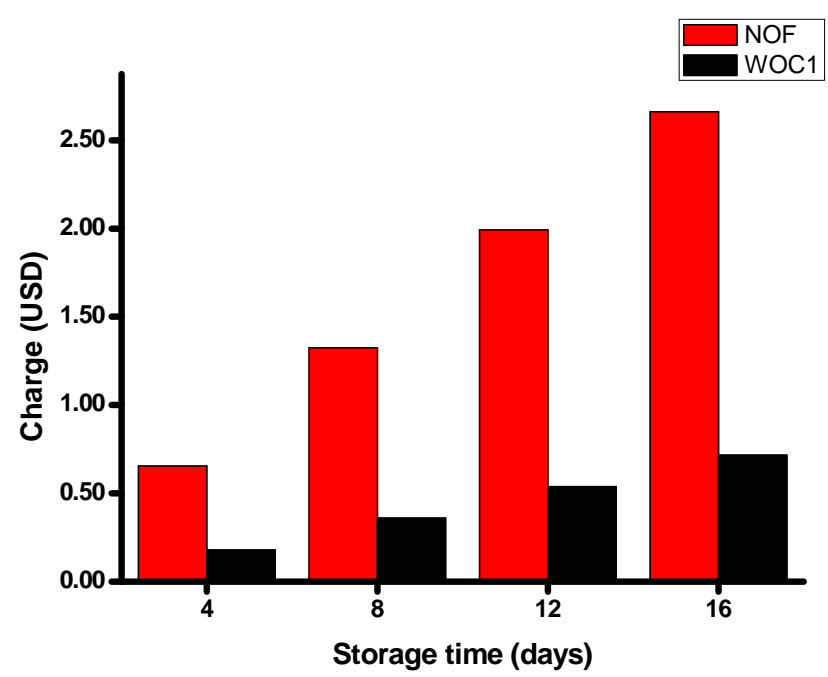

Fig. 10. Comparison of charge (in r) in non-ozone freezer and with ozone compartment 1 as function of storage time 
Table 1 shows the difference between the TVBN on every treatment using ozone to safe storage without ozone. The analysis will look for is the energy efficiency and cost of the storage process. The process of storing the freezer without ozone used as a comparison. This is because, using freezer storage requires great energy. A striking difference occurs between the use of the freezer without ozone with use of the rack 1 using ozone. In the freezer without the use of ozone, the fish were stored for 8 days has TVBN value of 12.42. Energy and the costs involved in the process of $17.04 \mathrm{kWh}$ and 1.324 US\$. While the use of rack 1 using ozone, fish stored for 8 days has TVBN value of 9.69. Energy and the costs involved in the process of $4.63 \mathrm{kwh}$ and 0.36 US\$. The conclusion that can be obtained is the use of ozone can reduce the energy load required, because ozone is able to help preserve the refrigerator temperature is higher than using a low temperature without ozone.

\section{CONCLUSION}

In this paper obtained that the use of ozone can maintain the quality of stored fish in refrigeratorwith high enoughenergy savings. The quality of the fish was obtained by observing TVBN and it was found that TVBN was still included in the INS standard.Tests on samples of mackerel fish ozonized, we found that organoleptic of sample was still meet the fresh fish standard according to INS. Ozonation onmackerel fish can maintain the value of TVBN.The quality canbe mantained is due to the growth of bacterial colonies in the fish can be controlled by exposure of ozone in refregirator. The results showed that the value of the fish in the refrigerator TVBN powered ozone standards are still maintained in the range of fresh fish in accordance with INS, which is below the value of 30 . While the value TVBN in fish stored in a refrigerator is not energized ozone tends to be higher than those fed ozone, TVBN value in fish stored in the refrigerator without ozone wasperishable on the 12 th day of each compartment, reaching 30, except in the freezer compartment. On the 16th day, through comparasion of fish freshness (TVBN value), refrigerator not powered by ozone can only be represented by fish stored in the freezer at tempertaure of $-9.28^{\circ} \mathrm{C}$. The energy consumed by refrigerator not powered by ozone was $34.26 \mathrm{kWh}$ compared to $9.23 \mathrm{kWh}$ for refrigerator powered by ozone. These results indicate a huge energy savings ( $73 \%$ ) by utilizing ozone in the refrigerator.The use of ozone technology in storage systems of fish in the refrigerator potential in saving energy consumed for cooling system.

\section{ACKNOWLEDGMENT}

The authors wish to thank to the Ministry of Research and Technology Republic of Indonesia for funding this implementation research through the program Sinas 2014 byInsinas 2014, Identity number: RT-2014-1008

\section{REFERENCES}

[1] Xu H, Zhang ZL, Zhang JH, Liu H, Zhao P, Shi R, Wang J, He YP. The research development proposals on fishery energy saving and emission reduction China. J Fish China 2011;35(3):472-80.

[2] Xu Xiangguo, Li Yishu, Yang ShenYin, Chen Guangming, 2017, A review of fishing vessel refrigeration systems driven by exhaust heat from engines, Applied Energy, 203:657-676.

[3] Hoang, H.M., Brown, T., Indergard, E., Leducq, D., Alvarez, G., a Life cycle assessment of salmon cold chains: comparison between chilling and superchilling technologies, Journal of Cleaner Production, vol 126 pp 363-372 2016

[4] Muhammad Nur, Maryam Resti, Fajar Arianto, Zaenul Muhlisin, Sosiowati Teke, Ade Ika Susan, Endang Kusdiyantini, Wuryanti, “Development of Ozone Technology Fish StorageSystems for Improving Quality Fish Production”, ISTMET 2014, IEEE Xplore, pp. $167-172,2014$

[5] Zisheng, Lu., Ruzhu, Wang., Experimental performance study of sorption refrigerators driven by waste gases from fishing vessels diesel engine, Applied Energy, vol 174, pp 224-231, 2016.

[6] Wang R.Z.,"Recent developments of refrigeration technology in fishing vessels" Renewable Energy 30, pp. 589-600, 2005

[7] John D. Fagan, T. Ronan Gormley, Mary Uí Mhuircheartaigh, "Effect of freeze-chilling, in comparison with fresh, chilling and freezing, on some quality parameters of raw whiting, mackerel and salmon portions," LWT - Food Science and Technology, Vol. 36, Issue 7, pp. 647-655, Nov. 2003.

[8] Hernandez and M.D. Garrido, Sensory, physical, chemical and microbiological changes in aquacultured meagre (Argyrosomusregius) fillets during ice storage, J. food chemistry, 114(1):237-245.

[9] Ilias Siskos, Anastasios Zotos, Styliani Melidou, Roussa Tsikritzi, "The effect of liquid smoking of fillets of trout (Salmo gairdnerii) on sensory, microbiological and chemical changes during chilled storage”, Food Chemistry, pp. 458-464, Vol. 101, 2007

[10] Campos, C.A., Losada, V., Rodriguez, O.. Aubourg, S.P., Velazquez, J.B., "Evaluation of an Ozone-Slurry ice Combined RefrigerationSystem for the Storage of Farmed Turbot (Psetta Maxima), Journal of Food Chemistry, vol. 97, pp. 223-230, 2006

[11] BegoñaMúgica, Jorge Barros-Velázquez, José M.Miranda, Santiago P.Aubourg, 2008, Evaluation of a slurry ice system for the commercialization of ray (Raja clavata): Effects on spoilage mechanisms directly affecting quality loss and shelf-life, LWT - Food Science and Technology, vol 41(6):974-981.

[12] B.Zambuchini, D.Fiorini, M.C.Verdenelli, C.Orpianesi, R.Ballini, 2008, Inhibition of microbiological activity during sole (Soleasolea L.) chilled storage by applying ellagic and ascorbic acids, LWT - Food Science and Technology, vol.41(9):1733-1738.

[13] Pastoriza, L. Bernardez, M. Sampedro, G. Cabo, M.L. and Herrera,J.J.R., Use of Sterile and Ozonized Water as a Strategy to Stabilize the Quality of Stored refrigerated Fresh Fish," Journal of Food Control, vol. 19, pp. 772-780, 2008

[14] Nur, M., Susan, A.I, Muhlisin, Z., Arianto, F., Kinandana, A.W., Nurhasanah, I., Sumariyah, S., Wibawa, P. J., Gunawan, G., and Usman, A., "Evaluation of Novel Integrated Dielectric Barrier Discharge Plasma as Ozone Generator" Bulletin of Chemical Reaction Engineering \& Catalysis; Semarang Vol. 12, Iss. 1, pp. 24-31, 2017

[15] Indonesian National Standard INS 2354.8:2009, Chemical Test Method-Chapter 8:The Determination of Total Volatile Base Nitrogen (TVB-N) and TrimetilAmin Nitrogen (TMA-N) Levels in Fishery Product, BNSI, Jakarta, 2009

[16] Indonesian National Standard, INS 01-2729.1-2006, Fresh Fish - Chapter1: Spesification, BNSI, Jakarta, 2006

[17] Wen-long Cheng, Miao Ding, Xu-dong Yuan, Bing-Chuan Han , "Analysis of energy saving performance for household refrigerator with thermal storage of condenser and evaporator", Energy Conversion and Management 132, pp. 180-188, 2017 
[18] Daishin Okada, Noboru Segawa, Takehsi Imamura, Takao Hattori, Takumi Oikawa," Refrigerator and Deodorizer Producing Ozone by High-Voltage Discharge", U.S. Patent, 0037240 A1 Mar. 22, 2002. Available:https://patents.google.com/patent/US20020037240A1/en

[19] Abbas, K.A., Abdulkarim, S.M., and Jamillah, B., 2008, Thermophysical properties of some species of Malaysian freshwater fish in unfrozen state, J. Food, Agriculture \& Environment, vol.6(2):14-18.

[20] Crowe, K.M. Skonberg, D. Bushway, Al., and Baxter, S.,"Application of Ozone Sprays as a Strategy to Improve the Microbial Safety andQuality of Salmon Fillets", Jornal of Food Control, vol 25. pp. 464- 468, 2012

[21] Manousaridis, G. Nerantzaki, A. Paleologos, E.K. Tsiotsias, A., Savvaidis, I.N. Kontominas, M.G., "Effect of Ozone on Microbial, Chemical and Sensory Atrributes of Shucked Mussels," Journal of Food Microbiology, vol. 22. 2005, pp. 1 - 9

[22] Vaz-Velho, M. Silva, M., Pessoa, J., Gibbs, P., Inactivation by Ozone of Listeria Innocua on Salmon-Trout During Cold-Smoke Processing, Journal of Food Control, vol. 17.pp.609-616, 2006 